\title{
Strategy for the Development of Dried Shrimp Short Processing in Sumber Rejeki Sejahtera Group, Cirebon City
}

\author{
*Corresponding Author \\ Nasyiah \\ Article History \\ Received: 03.06.2020 \\ Accepted: 15.06 .2020 \\ Published: 20.06.2020
}

Nasyiah", Darmanto YS, Wijayanto D

Faculty of Fisheries and Marine Sciences, Diponegoro University, Indonesia

\begin{abstract}
Shredded shrimp production is still classified on a small scale with insufficient human resources, traditional technology, and an inadequate managerial system making weaknesses in business development experienced by the Sumber Rejeki Sejahtera Group. The purpose of this study is to formulate a priority strategy in developing shredded processing business. The method used in this research is a case study by conducting interviews using a questionnaire. Analysis of business development strategies using TOWS (Threats, Opportunities, Weakness, and Strengths) and QSPM (Quantitative Strategic Planning Matrix) approaches. The results of this study in the form of priority strategies in the development of dried shredded shrimp using QSPM analysis are to increase promotional activities, expand distribution and marketing networks to maintain product quality, product development, optimize business production volume, improve services to consumers and distributors, improve the quality of human resources.
\end{abstract}

Keywords: Business Development Strategy, Shredded Shrimp, QSPM.

\section{INTRODUCTION}

Shredded dried shrimp is one of the processed fishery products made from dried shrimp raw materials. Dried shrimp which is used as raw material for processing shredded dried shrimp has a bright appearance, clean with an orange color, and has a musty odor. According to [1], the types of shrimp that are commonly used as raw materials for dried shrimp are fire shrimp (Metapenaeus monoceros) and crustaceans (Metapenaeus lysianassa).

Shredded fish is a dry food made from meat and spices. Material is boiled or steamed, then chopped, mixed with herbs and fried until cooked to floss. Abon making can be used as an alternative utilization of fishery products by small and medium-sized businesses [2, 3].

Shredded dried shrimp products in Cirebon City are produced by the Sumber Rejeki Sejatera Group. Shredded dried shrimp is pretty much in demand by consumers. High consumer interest in these products does not prevent this business from problems. Capital, technology, market access, product competition also become obstacles in business development. These obstacles can be overcome by implementing the right strategy so that the business can develop. The purpose of this research is to determine the right priority strategy for the Sumber Rejeki Sejatera Group in developing its business.

The research was conducted from December 2019 to January 2020. The research location was conducted at the production of dried shredded shrimps in the Sumber Rejeki Sejahtera Group, located in Panjunan, Lemahwutut District, Cirebon City, and West Java Province.

\section{MeTHODS}

The method used in this research is a study using a survey method using a questionnaire. The questionnaire was aimed at 15 subjects. Analysis of the data used in this study uses the TOWS analysis approach. The stages of the analysis

Copyright @ 2020: This is an open-access article distributed under the terms of the Creative Commons Attribution license which permits unrestricted use, distribution, and reproduction in any medium for non commercial use (NonCommercial, or CC-BY-NC) provided the original author and source are credited. 
are: 1) determining the weights (1-3) for internal and external factors; 2) rating (1-4) on internal and external factors; 3 ) conducting IFAS (Internal Strategic Factors Analysis Summary) and EFAS (External Strategic Factors Analysis Summary) matrix analysis; 4) carry out IE analysis (Internal External); 5) conduct TOWS analysis (Threats, Opportunities, Weakness, and Strengths); and 6) Determine priority strategies using QSPM (Quantitative Strategic Planning Matrix) analysis.

\section{RESULTS AND DiSCUSSION}

The process of making shredded dried shrimp is done by grinding dried shrimp and then cooked with spices until cooked. Shredded dried shrimp has a distinctive savory taste with a golden brown appearance.

IFAS matrix analysis is done by analyzing the Strengths and Weakness factors in the processing of shredded shrimp. The results of IFAS matrix analysis are presented in table 1.

Table-1: IFAS Matrix in the Development of Shrimp Shredded Processing Business

\begin{tabular}{|c|c|c|c|c|}
\hline \multirow[t]{2}{*}{ No. } & Internal Factor & \multirow[t]{2}{*}{ Weight } & \multirow[t]{2}{*}{ Rating } & \multirow[t]{2}{*}{ Value } \\
\hline & Strengths & & & \\
\hline 1 & Strategic location with adequate infrastructure & 0,087 & 3 & 0,261 \\
\hline 2 & the taste and quality of the product has characteristics & 0,086 & 4 & 0,314 \\
\hline 3 & Have attractive packaging and labels & 0,083 & 4 & 0,333 \\
\hline 4 & business experience & 0,087 & 3 & 0,233 \\
\hline 5 & strong family relations and cooperation & 0,104 & 3 & 0,277 \\
\hline \multicolumn{2}{|l|}{ Total } & 0,447 & 16 & 1,418 \\
\hline & \multicolumn{4}{|l|}{ Weakness } \\
\hline 1 & limited capital funds & 0,089 & 3 & 0,268 \\
\hline 2 & processing technology that is still simple & 0,109 & 4 & 0,399 \\
\hline 3 & $\begin{array}{l}\text { The processing location is far from the source of raw } \\
\text { materials }\end{array}$ & 0,092 & 3 & 0,308 \\
\hline 4 & low quality human resources & 0,097 & 4 & 0,357 \\
\hline 5 & lack of product promotion & 0,080 & 4 & 0,294 \\
\hline 6 & production capacity is not optimal & 0,085 & 3 & 0,255 \\
\hline \multicolumn{2}{|c|}{ Amount } & 0,553 & 20 & 1,880 \\
\hline \multicolumn{2}{|c|}{ Total } & 1.00 & 36 & 3,298 \\
\hline
\end{tabular}

Strategic location with adequate infrastructure rated 0.261 . The location of dried shredded shrimp is only $3-5 \mathrm{~km}$ away from the marketing area and has good road access, making it easier to distribute goods that can reduce transportation costs. The taste and quality of products that have characteristics are given a value of 0.314 . Shredded dried shrimp has a distinctive savory taste of dried shrimp that can be enjoyed as an addition to side dishes with the characteristic presence of the addition of fried shallots.

Have attractive packaging and labels rated 0.333. The packaging used for dried shredded products is a plastic jar that can make it easier for consumers to buy. The label on the package includes the trademark, date of production, expiration date, origin of production, composition of dried shredded product and product certification obtained. This is in accordance with the opinion of Mukhtar \& Nurif [4], which states that the packaging label has several functions, namely showing the product and identifying products such as manufacturers, processing locations, composition and how to consume them.

Business experience is rated 0.233. Sumber Rejeki Sejahtera Group has been doing shredded shrimp processing business for 5 years. The length of the business not only provides additional innovation in improving product quality but also in solving problems that occur in the business activity and creating a network of relationships in the business. Family relations and strong cooperation are given a value of 0.277. Members of the Sumber Rejeki Sejahtera group are still within the scope of the family, so in conducting production activities they are willing to contribute their energy to production activities in accordance with the division of their tasks.

Limited capital funds are given a value of 0.268 . The initial capital of shredded shrimp processing business is Rp. $5,000,000.00$. Used to buy shredded processing equipment that is simple and raw materials and additives. Hartono \& Hartomo [5], capital is a crucial problem that is often experienced by SMEs. This problem can hamper product innovation and transformation so that it will hamper business activities. 
Simple processing technology is given a value of 0.399 . The processing of shredded dried shrimp is still done using simple tools. The processing location far from the source of raw materials is given a value of 0.308 . The raw material used is dried shrimp obtained from Losari Regency which is $>30 \mathrm{~km}$ away.

The low quality of human resources is given a value of 0.357 . The low quality of human resources makes the processing process still unable to implement Good Manufacturing Practice (GMP) and good standard operational sanitation procedures (SSOP). The lack of product promotion was given a value of 0.294. Promotion is done by entering the product into a gift shop and marketing by word of mouth. Not optimal production capacity rated 0.255 . For a year the Sumber Rejeki Sejatera group was only able to produce as much as 3000 shredded shredded shrimp.

EFAS matrix analysis is done by analyzing Opportunities and Threats in the processing of shredded shrimp. The results of the EFAS matrix analysis for shredded shrimp processing presented in Table 2 are as follows:

Table-2: EFAS Matrix in the Development of Shrimp Shredded Processing Business

\begin{tabular}{|l|l|c|c|l|}
\hline \multirow{2}{*}{ No. } & \multicolumn{1}{|c|}{ External Factor } & Weight & Rating & Value \\
\cline { 2 - 4 } & Opportunities & & \\
\hline 1 & Support from the Cirebon City government & 0,152 & 2 & 0,375 \\
\hline 2 & The development of increasingly advanced technology & 0,153 & 3 & 0,532 \\
\hline 3 & High market demand & 0,140 & 4 & 0,561 \\
\hline & amount & 0,446 & 9 & 1,468 \\
\hline & Threats & & \\
\hline 1 & Fluctuating prices of raw materials or additives & 0,144 & 2 & 0,354 \\
\hline 2 & The threat of entry of newcomers is quite large & 0,122 & 2 & 0,301 \\
\hline 3 & Availability of raw materials due to seasonal changes & 0,134 & 3 & 0,403 \\
\hline 4 & The purchasing power of customers is decreasing & 0,154 & 3 & 0,535 \\
\hline & amount & 0,554 & 10 & 1,593 \\
\hline \multicolumn{2}{|l|}{ Total } & 1.00 & 19 & 3,061 \\
\hline
\end{tabular}

Support from the Cirebon city government was given a value of 0.375 . The role of the regional government is not only in providing guidance to business development but also in the form of group facilitation to add facilities and infrastructure with assistance programs.

The development of increasingly advanced technology is given a value of 0.532 . In the era of the industrial revolution 4.0, the development of technology has increased rapidly, such as the tools used in the production process and product marketing activities. These developments have a positive effect, so that the production process runs effectively and efficiently. Hamdan [6] states the 4.0 industrial revolution had an influence on humans. Science and technology that are developing rapidly can create technology in terms of information and production processes that are run automatically and in a controlled manner. This makes economic improvement so that entrepreneurs will become economically independent.

The high market demand is given a value of 0.561. The Sumber Rejeki Sejahtera group is able to produce 250 jars each month, while the market demand for dried shredded products from a souvenir shop and some resellers can dry from 300 jars if they enter a long holiday. According to Hutagalung \& Syafrizal [7] demand for products is related to economic growth. Good economic growth will increase demand.

The price of fluctuating raw materials or additives is given a value of 0.354 . The instability of the price of raw materials and additives will make the warehouse producers dry up and become a threat to the financials of the business. The entry of new arrivals which was quite high was given a value of 0.301 . In Cirebon region, there are no producers processing the same shredded products. However, this can pose a threat because with an easy processing with high selling prices and market demand, it is estimated that many processors will produce dried shredded shrimp.

The availability of raw materials due to seasonal changes is given a value of 0.403 . Dried shrimp raw material is very influential on the season. The dried shrimp that is used must be completely dry so that it will be easier in the grinding process. Shrimp that are less dry will affect the smell and taste of shredded dried shrimp. Dried shrimp that are really dry will be easily obtained in the dry season, while in the rainy season the price will be expensive and not too much available. The purchasing power of customers has been decreased by 0.535 . Declining consumer purchasing power is one of the threats that producers are very worried about in their business development efforts. Declining purchasing power will have a direct impact on business finances so it will be difficult for the business to develop. 
The next analysis is the internal-external matrix (IE) analysis. IE Matrix aims to determine the position of the Sumber Rejeki Sejahtera Group in developing dried shredded products so that it makes it easier to determine the right strategy. The results of the IE matrix can be seen in Figure 1.

The results in the IE matrix illustrate that shredded processing business in the Sumber Rejeki Sejahtera group is in quadrant I. Quadrant I is a development and growth zone. According to Warcito \& Saleh [8]. The right strategy to apply in the growth and development zone is with an intensive strategy. An intensive strategy can be carried out by penetrating markets, developing markets, and developing products.

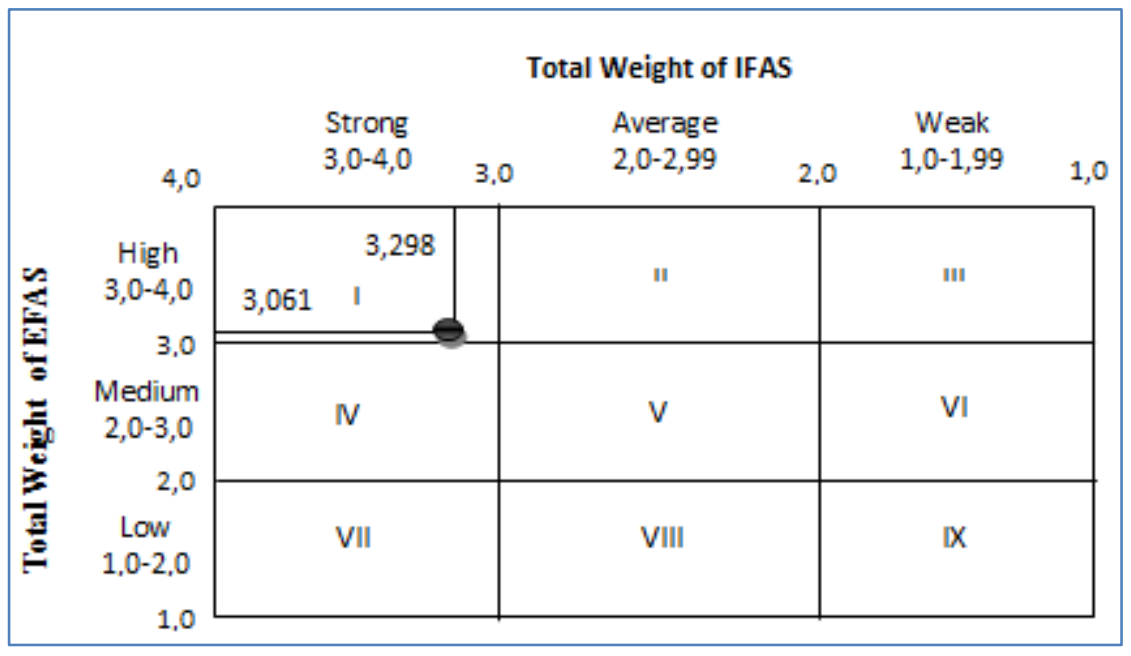

Fig-1: IE Matrix

TOWS analysis is carried out to combine opportunities-threats-strengths and weaknesses to produce strategies that can be used as alternatives in developing shredded processing business. TOWS analysis is presented in Table 3.

Table-3: Matrix of TOWS Processing of Shredded Shrimp in the sumber rejeki sejahtera group

\begin{tabular}{|c|c|c|}
\hline & Strength (S) & Weakness (W) \\
\hline $\begin{array}{l}\text { Internal Factor } \\
\text { External Factor }\end{array}$ & $\begin{array}{l}\text { S1 Smooth distribution and } \\
\text { transportation channel } \\
\text { S2 The taste and quality of the } \\
\text { product has characteristics } \\
\text { S3 has a packaging label } \\
\text { S4 business experience } \\
\text { S5 there is strong family relations } \\
\text { and cooperation }\end{array}$ & $\begin{array}{l}\text { W1 limited capital } \\
\text { W2 processing technology is still simple } \\
\text { W3 The processing location is far from } \\
\text { the source of raw materials } \\
\text { W4 low quality human resources } \\
\text { W5 lack of product promotion } \\
\text { W6 production capacity is not optimal }\end{array}$ \\
\hline \multicolumn{3}{|l|}{ Opportunity (O) } \\
\hline $\begin{array}{l}\text { O1 Support from the Cirebon } \\
\text { City government } \\
\text { O2 Development of increasingly } \\
\text { advanced technology } \\
\text { O3 High market demand }\end{array}$ & $\begin{array}{l}\text { Maintaining product quality (S2, } \\
\text { S3, S4, O2, O3) } \\
\text { Expanding distribution and } \\
\text { marketing networks (S1, S4, S5, } \\
\text { O1) }\end{array}$ & $\begin{array}{l}\text { Increase promotion activities (W5, O1, } \\
\text { O2, O3) } \\
\text { Optimize business production volume } \\
(\mathrm{W} 1, \mathrm{~W} 2, \mathrm{~W} 3, \mathrm{~W} 4, \mathrm{~W} 6, \mathrm{O} 1, \mathrm{O} 2, \mathrm{O} 3)\end{array}$ \\
\hline \multicolumn{3}{|l|}{ Threat $(\mathbf{T})$} \\
\hline $\begin{array}{l}\text { T1 Prices of raw materials or } \\
\text { additives are volatile } \\
\text { T2 The threat of entry of new } \\
\text { arrivals is quite large } \\
\text { T3 Availability of raw materials } \\
\text { due to seasonal changes } \\
\text { T4 Customer purchasing power } \\
\text { decreases }\end{array}$ & $\begin{array}{l}\text { Improve services to consumers and } \\
\text { distributors (S1, S2, S3, S4, S5, T1, } \\
\text { T2, T3, T4) }\end{array}$ & $\begin{array}{l}\text { Improving the quality of human resources } \\
\text { (W1, W2, W3, W4, W5, T1, T2, T3, T4) } \\
\text { Product Development (W1, W2, W5, W6, } \\
\text { T1, T2, T4) }\end{array}$ \\
\hline
\end{tabular}

The strategy priority for the development of dried shredded business is carried out by QSPM analysis in determining the relative attractiveness of each strategy. QSPM analysis results can be seen in table 4. 
Table-4: QSPM Analysis of Dry Shredded Processing in Sumber Rejeki Sejahtera Group

\begin{tabular}{|c|l|c|l|}
\hline No. & \multicolumn{1}{|c|}{ Strategy } & TAS & Priority \\
\hline 1 & Increase promotional activities & 6,359 & Priority 1 \\
\hline 2 & Expanding distribution and marketing networks & 5,290 & Priority 2 \\
\hline 3 & Maintaining product quality & 5,197 & Priority 3 \\
\hline 4 & Product Development & 5,160 & Priority 4 \\
\hline 5 & Optimizing business production volume & 5,083 & Priority 5 \\
\hline 6 & Improve services to consumers and distributors & 5,078 & Priority 6 \\
\hline 7 & Improving the quality of human resources & 5,074 & Priority 7 \\
\hline
\end{tabular}

The strategy to increase promotion of dried shredded products can be done in a direct way, namely by promoting products in activities, both from government and others such as bazaars. Promotion can be done indirectly by utilizing the latest technological advances, namely by accessing the internet by utilizing social media such as Facebook, Instagram and others. This strategy is in accordance with research conducted by Aliyah et al., [9], namely the application of promotion strategies to Abon Houses in Bandung. Promotional activities carried out by promoting products using internet access and following the bazaar.

Expanding distribution and marketing networks can be done by selling products through reseallers and selling products through gift shops and in collaboration with local governments and travel agents. This is in accordance with the research of Setiyorini et al., [10] concerning marketing strategies. The expansion of marketing networks can take advantage of the existence of a souvenir shop at a new tourist location that is crowded with visitors. These suppliers can create a chain of impact in expanding marketing territory and sales targets.

Maintaining product quality is a strategy that can be done by maintaining the consistency of shredded quality by applying GMP and SSOP when processing activities. The distinctive feature of dried shredded shrimp produced by Sumber Rejeki Sejahtera group is that the addition of fried onions needs to be maintained because it will be a difference with other shredded products.

Product development can be done by doing product innovation both innovation from the type of raw materials and processing. Development of products can also be done by providing new variants of packaging, such as making dried shredded products with economical packaging. Fatmasari [11], Product development can be done by diversifying products with the aim of expanding the market so that business profits can increase.

The strategy to optimize the volume of business production can be done by optimizing the supply of raw materials, capital and human resources and improving the technology owned so that the amount of demand desired by the market. According to Aliyah [9], the application of appropriate technology can create work efficiency and improve the quality and quantity of products. The optimal application of this technology will increase production volumes so that demand can be met and revenues can increase.

Increasing the quality of service to consumers and distributors can be in the form of delivery services with several conditions such as minimum purchases and delivery distances. Service for complaints must also be done well and politely. According to Djoni $[12,13]$, trust and loyalty in doing business can be created by providing good service to consumers.

Improving the quality of human resources can be done by attending training and education activities. The training is expected to change the way of thinking that is still traditional to modern and can think effectively and efficiently to develop shredded products.

\section{Conclusion}

Appropriate priority strategy for developing Abon Ebi (Shredded Shrimp) processing business is to increase promotional activities with a TAS value of 6.359 as priority 1, expand distribution and marketing networks with a value of TAS 5,290 as priority 2, maintain product quality with a value of TAS 5,197 as priority 3, product development with the value of TAS 5,160 as priority 4, optimize the volume of business production with a value of TAS 5,083 as priority 5, improve services to consumers and distributors with a value of TAS 5,078 as priority 6, and improve the quality of human resources with a value of TAS 5,074 as priority 7 .

\section{THANK-YOU NOTE}

The authors thank my husband, children and extended family and friends who have provided motivation and enthusiasm to complete this thesis. thank you [the authors convey to the extended family of the Department of 
Agriculture, Maritime and Fisheries of the City of Cirebon, which gave the author the opportunity to complete his S2 study at Diponegoro University, Indonesia.

\section{REFERENCES}

1. Fadli, A., Drastinawati, D., Alexander, O., \& Huda, F. (2017). Pengaruh rasio massa kitin/NaOH dan waktu reaksi terhadap karakteristik kitosan yang disintesis dari limbah industri udang kering. Jurnal Sains Materi Indonesia, 18(2), 61.

2. Latif, R., Dirpan, A., \& Indriani, S. (2017, December). The Status of Implementation of Good Manufacturing Practices (GMP) Shredded Fish Production in UMKM Az-Zahrah, Makassar. In IOP Conference Series: Earth and Environmental Science (Vol. 101, No. 1, p. 012040). IOP Publishing.

3. Abriana, A., Indrawati, E., \& Rahman, R. (2020). Development of Regional Excellence Potentials Through Food Diversification Based on Local Resources. In 5th International Conference on Food, Agriculture and Natural Resources (FANRes 2019) (pp. 164-168). Atlantis Press.

4. Mukhtar, S., \& Nurif, M. (2015). Peranan Packaging Dalam Meningkatkan Hasil Produksi Terhadap Konsumen. Jurnal Sosial Humaniora, 8(2), 181-191.

5. Hartono, H., \& Hartomo, D. D. (2018). Faktor-Faktor Yang Mempengaruhi Perkembangan Umkm Di Surakarta. Jurnal Bisnis dan Manajemen (Journal of Business and Management), 14(1), 15-30.

6. Hamdan, H. (2018). Industri 4.0: Pengaruh Revolusi Industri Pada Kewirausahaan Demi Kemandirian Ekonomi. Jurnal Nusantara Aplikasi Manajemen Bisnis, 3(2), 1-8.

7. Hutagalung, R. B., \& Syafrizal, H.S. (2008). Pengantar Kewirausahaan. Medan: USU Press.

8. Warcito dan Amiruddin S. 2016. Strategi Pengembangan Usaha Mikro dan Kecil pada Usaha Pengolahan Pangan. Jurnal Manajemen 7(2): 172-180.

9. Aliyah, R., Gumilar, I., \& Maulina, I. (2015). Strategi Pengembangan Usaha Pengolahan Abon Ikan (Studi Kasus Rumah Abon Di Kota Bandung). Jurnal Perikanan Kelautan, 6(2), 1.

10. Setiyorini, E. S., Noorachmat, B. P., \& Syamsun, M. (2018). STRATEGI pemasaran produk olahan hasil perikanan pada UMKM Cindy Group. MANAJEMEN IKM: Jurnal Manajemen Pengembangan Industri Kecil Menengah, 13(1), 19-28.

11. Fatmasari, D. F. D. (2018). Peluang Usaha Melalui Diversifikasi Produk Berbahan Baku Ikan Lele Di Desa Karangsari Kecamatan Karangtengah Kabubaten Demak. Majalah Ilmiah Inspiratif, 3(6).

12. Djoni, D. (2018). Strategi Pengembangan Bisnis Ikan Hias Cupang (Betta Sp) Di Pangkalan Bun, Kotawaringin Barat. JURISTEK, 5(2), 182-187.

13. Warcito, W., \& Saleh, A. (2016). Strategi Pengembangan Usaha Mikro dan Kecil Pada Usaha Pengolahan Pangan. Jurnal Manajemen (Edisi Elektronik), 7(2), 172-180. 